\title{
QSAR AND MOLECULAR DOCKING APPROACHES FOR DEVELOPMENT OF HALOXANTHONES AS THE ANTICANCER AGENT AGAINST MCF-7 AND HepG2
}

\author{
T.H. Sugara ${ }^{1,2}$, Jumina ${ }^{2, \bowtie}$, E.N. Solikhah ${ }^{3}$ and H.D. Pranowo ${ }^{2}$ \\ ${ }^{1}$ Departement of Pharmacy, Faculty of Health Sciences, Muhammadiyah University of Mataram, \\ 83115, West Nusa Tenggara, Indonesia \\ ${ }^{2}$ Departement of Chemistry, Faculty of Mathematics and Natural Sciences, \\ Universitas Gadjah Mada, 55281, Yogyakarta, Indonesia \\ ${ }^{3}$ Departement of Pharmacology and Therapy, Faculty of Medicine, Public Health, and Nursing. \\ Universitas Gadjah Mada, 55281, Yogyakarta, Indonesia \\ Corresponding Author: jumina@ugm.ac.id
}

\begin{abstract}
The development of haloxanthones as potential anticancer agents is critical since their derivatives have remarkable cytotoxicity against several cancer cell lines. This study aims to explore the anticancer activity of haloxanthones against liver cancer (HepG2) and Breast cancer (MCF-7) based on the Quantitative Structure-Activity Relationship (QSAR) and molecular docking approaches. Through the QSAR study, we found that the lowest unoccupied molecular orbital energy, dipole moment, and atomic charges on $\mathrm{C} 1, \mathrm{C} 4$, and $\mathrm{C} 6$ affect the anticancer activity of haloxanthones against MCF-7 cell line. Meanwhile, the atomic charges on C7, C8, C8a, and O11 of haloxanthones affect the anticancer activity against HepG2 cell line. The prediction of the anticancer activity of 26 haloxanthone derivatives showed that they belong to the strong category $\left(\mathrm{IC}_{50}\right.$ predictive $\left.<6.25 \mu \mathrm{g} / \mathrm{mL}\right)$ according to the QSAR study. On the other hand, we found that the geometric structure of haloxanthone was not much different compared with the native ligand (0NR) that was bound to the c-JNK protein (RMSD $<2 \AA$ ) on the molecular docking study. It was found that haloxanthones were able to interact with c-JNK protein through hydrogen bonds (MET111 and GLU109), alkyl/pi-alkyl (VAL40), and halogen interactions (MET108, ASP112), which is remarkable.
\end{abstract}

Keywords: QSAR, Molecular Docking, Haloxanthone, Anticancer, HepG2 and MCF-7.

RASĀYAN J. Chem., Vol. 14, No.3, 2021

\section{INTRODUCTION}

In 2018, it was reported that cancer causes the death of 9.6 million people thus cancer was mentioned as the second most global fatal disease. ${ }^{1}$ Breast cancer (MCF-7) and liver cancer (HepG2) are the most significant contributors to human death among the other cell lines. A high number of cancer cases is worsened since some cancer cell lines are resistant to standard drug compounds, such as 5-fluorouracil, cisplatin, cytarabine, and doxorubicin. ${ }^{2}$ Various efforts are given by researchers to find new potential drug compounds for cancer therapy.

One of the potential drug compounds is xanthone derivative. The structure of xanthone is shown in Figure1. It has been reported that xanthone derivatives are known to have good anticancer activity, such as haloxanthone, ${ }^{3-5}$ hydroxyxanthone, ${ }^{6}$ 3,6-diamino carbonyl methoxy xanthone, ${ }^{7} \alpha$-mangosteen, ${ }^{8-15} \beta$ mangosteen, ${ }^{16} \gamma$-mangosteen, ${ }^{15}$ garcinone $\mathrm{D},{ }^{17}$ and gartanin. ${ }^{18}$ The xanthone derivatives enhance the apoptosis of the cancer cell by stimulating various caspase enzymes and increasing Bax protein. ${ }^{8-10}$ Furthermore, xanthone derivatives also retard the cancer cell cycle through inhibition of various cyclines, Bcl-2 and nuclear factor-kappa B/NF- $\kappa \mathrm{B} .{ }^{8,19-21}$

In the last recent years, anticancer activity studies of xanthones have been focused on the haloxanthone derivatives. Haloxanthone is a xanthone derivative with one or more halogen $(\mathrm{F}, \mathrm{Cl}, \mathrm{Br}$, or I) substituents. It was reported that both chloro and bromo substituted xanthones have higher activity as an anticancer than

Rasayan J. Chem., 14(3), 1927-1937(2021)

http://doi.org/10.31788/RJC.2021.1436214

This work is licensed under a CC BY 4.0 license. 
the unmodified xanthone itself. ${ }^{16-18}$ However, the anticancer activity of haloxanthones still needs to be developed because their molecular interaction with the targeted proteins is still unknown.

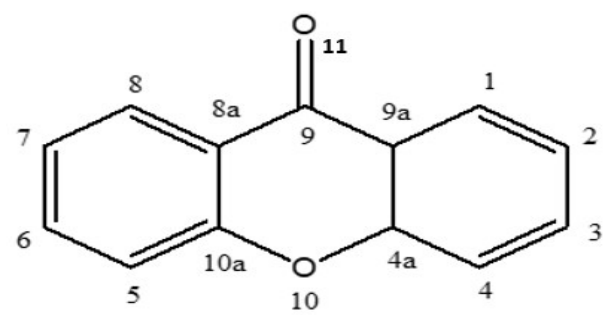

Fig.-1: The Chemical Structure of Xanthone

Therefore, this study is conducted to investigate the anticancer activity of haloxanthones through Quantitative Structure-Activity Relationship (QSAR) and molecular docking approaches. Both approaches play an essential role in discovering and developing potential drug compounds. QSAR, also known as structure-based drug design (SBDD), is a study of the suitability of molecular structure (microscopic) with its pharmacological (macroscopic/empirical) activity. Meanwhile, molecular docking, also known as ligand-based drug design (LBDD), studies the binding between the targeted protein with the drug candidate from a three-dimensional point of view.

\section{EXPERIMENTAL \\ Quantitative Structure-Activity Relationship (QSAR) \\ Experimental Data}

The chemical structure and anticancer activity of xanthone derivatives (33 compounds) were taken from reported literature. ${ }^{5}$ The data used were xanthone derivatives with $\mathrm{IC}_{50}$ value $\leq 25 \mu \mathrm{g} / \mathrm{mL}$ for each cancer cell line. The $\mathrm{IC}_{50}$ values were then converted to $\log \mathrm{IC}_{50}$.

\section{Calculation of Molecular Descriptors}

${ }^{1}$ H-NMR chemical shifts of compound 1 (1,3-dihydroxy-7-chloroxanthone) were calculated using the AM1 (Austin Model 1), PM3 (Parameterized Model Number 3), ab initio, and DFT (Density Functional Theory) methodes. The obtained results were compared with the experimental ${ }^{1} \mathrm{H}-\mathrm{NMR}$ chemical shifts value. All quantum mechanical calculation was conducted using Gaussian 09 (AIC Laboratory, Departement of Chemistry, Universitas Gadjah Mada). Meanwhile, the correlation models were evaluated by multiple linear regression analysis using SPSS ${ }^{\circ}$ Release 23.0.0.

\section{Validation QSAR Model}

The best model was chosen based on some statistical parameters such as $r, r^{2}$, adjusted R, Standard Estimation of Error (SEE), PRESS, and $\mathrm{F}_{\mathrm{cal}} / \mathrm{F}_{\text {tab }}$. Furthermore, the best-selected model was used to calculated $\log \mathrm{IC}_{50}$ prediction of training and test set. The model was validated using criteria $\mathrm{r}^{2}$ prediction $>0.5 .^{22}$

\section{Molecular Docking Studies}

Protein Target Preparation

Three-dimensional structure of c-Jun protein N-terminal kinase (c-JNK) was obtained from the world protein data bank with the code 4e73.pdb.id with $0 \mathrm{NR}$ as the native ligand. The residue $\left(\mathrm{H}_{2} \mathrm{O}\right.$ molecules and standard ligands) was removed with the Chimera ${ }^{\circledR} 1.10$ program's help. The re-docking process was proceeded using the AutoDockTools 1.5.6 program's assistance to determine the interaction between native ligands and the targeted protein. The formed interactions were displayed using the Discovery studio® 3.1 software.

\section{Ligand Preparation}

Preparation of haloxanthone compounds as ligands was carried out by increasing the charge on each atom, making up the ligand, adding hydrogen atoms, and minimizing the energy. These processes were carried out using the Chimera ${ }^{\circledR} 1.10$ software. 


\section{Docking Process}

The docking process was first evaluated using standard ligands and had to get a Root Mean Square Deviation (RMSD) value less than $2 \AA$. After the docking method is validated, then the haloxanthone derivatives are docked on the target protein. The docking process was carried out using the BIOVIA Discovery Studio ${ }^{\circledR} 3.1$ software.

\section{Analysis of Docking Results}

The docking analysis stage was carried out using the Discovery studio ${ }^{\circledR} 4.5$ visualizer software. The interactions between targeted protein and ligands could be found in the form of hydrogen- and pi-bonds, which are distinguished based on the color of the bonds formed. In the Discovery studio software, the binding energy between a protein and a ligand could be determined. Smaller binding energy reflects stronger interaction between the targeted protein and the ligand. ${ }^{23}$

\section{RESULTS AND DISCUSSION}

\section{QSAR Model of Haloxanthones for MCF-7 and HepG2 Cancer Cell Lines}

The geometry structures of the xanthone derivatives were optimized using the Density Functional Theory (DFT) method with B3LYP/6-311G as a basis set. Afterward, the descriptor data were compiled from the Multiple Linear Regression (MLR) method to obtain a QSAR model. Optimization of 1,3-dihydroxyl-7chloroxanthone with the DFT method produced a prediction of ${ }^{1} \mathrm{H}-\mathrm{NMR}$ chemical shifts. It was found that the predicted ${ }^{1} \mathrm{H}-\mathrm{NMR}$ chemical shifts were closed to the experimental data in which the DFT B3LYP/6$311 \mathrm{G}$ gave the smallest PRESS value (see Tabel-1). The MLR analysis with the backward method provides five QSAR models for MCF-7 cancer cell lines and six QSAR models for HepG2 cancer cell lines (see Table-2).

Table-1: Predicted ${ }^{1}$ H-NMR Chemical Shift of 1,3-dihydroxyl-7-chloroxanthone Using PM3, PM6, AM1, HF, and $a b$ initio (DFT) Methods and its Comparison to The Experimental

\begin{tabular}{c|c|c|c|c|c|c|c|c|c|c|c}
\hline $\begin{array}{c}\text { Atom H } \\
\text { number }\end{array}$ & $\begin{array}{c}{ }^{1} \text { H-NMR } \\
\text { experiment }\end{array}$ & \multicolumn{2}{|c|}{ PM3 } & \multicolumn{2}{|c|}{ PM6 } & \multicolumn{2}{|c|}{ AM1 } & \multicolumn{3}{c|}{ HF } & \multicolumn{2}{c}{ DFT } \\
\hline H1 & 12.52 & 2.98 & 91.01 & 4.18 & 69.56 & 3.57 & 80.10 & 3.32 & 84.64 & 4.38 & 66.26 \\
\hline H2 & 6.23 & 4.41 & 3.31 & 4.46 & 3.13 & 4.47 & 3.10 & 3.71 & 6.35 & 4.92 & 1.72 \\
\hline H4 & 6.39 & 5.98 & 0.17 & 5.78 & 0.37 & 6.01 & 0.14 & 5.36 & 1.06 & 6.35 & 0.00 \\
\hline H5 & 7.63 & 6.70 & 0.86 & 6.70 & 0.86 & 6.82 & 0.66 & 6.17 & 2.13 & 6.96 & 0.45 \\
\hline H6 & 7.87 & 6.86 & 1.02 & 6.82 & 1.10 & 6.92 & 0.90 & 6.50 & 1.88 & 7.05 & 0.67 \\
\hline H8 & 8.00 & 7.69 & 0.10 & 7.76 & 0.06 & 7.92 & 0.01 & 7.73 & 0.07 & 8.04 & 0.00 \\
\hline
\end{tabular}

Table-2: QSAR Model for MCF-7 and HepG2 Cancer Cell Lines Based on MLR Analysis With the Backward Method

\begin{tabular}{|c|c|c|c|c|c|c|}
\hline Model & Descriptor & $\mathrm{r}$ & $r^{2}$ & Adjusted $R$ & SEE & $\mathrm{F}_{\text {cal. }} / \mathrm{F}_{\text {tab. }}$ \\
\hline \multicolumn{7}{|c|}{ MCF-7 Cancer Cell Lines } \\
\hline 1 & $\mathrm{qO} 11, \mathrm{qC} 6, \mathrm{qC} 8, \mathrm{qC} 3, \log \mathrm{P}, \mathrm{LUMO}, \mathrm{MD}, \mathrm{qC} 4, \mathrm{qC} 1$ & 0.97 & 0.94 & 0.88 & 0.17 & 4.29 \\
\hline 2 & $\mathrm{qO} 11, \mathrm{qC} 6, \mathrm{qC} 8, \mathrm{qC} 3, \mathrm{LUMO}, \mathrm{MD}, \mathrm{qC} 4, \mathrm{qC} 1$ & 0.96 & 0.93 & 0.87 & 0.18 & 4.75 \\
\hline 3 & qO11, qC6, qC8, LUMO, MD, qC4, qC1 & 0.95 & 0.91 & 0.85 & 0.19 & 4.67 \\
\hline 4 & qO11, qC6, LUMO, MD, qC4, qC1 & 0.95 & 0.89 & 0.84 & 0.20 & 4.96 \\
\hline 5 & qC6, LUMO, MD, qC4, qC1 & 0.94 & 0.88 & 0.83 & 0.21 & 5.46 \\
\hline \multicolumn{7}{|c|}{ HepG2 Cancer Cell Lines } \\
\hline 1 & qO11, qC1, qC7, qC6, BM, qC8, Log P, qC8a, qC9 & 0.99 & 0.97 & 0.94 & 0.11 & 8.32 \\
\hline 2 & $\mathrm{qO} 11, \mathrm{qC} 1, \mathrm{qC} 7, \mathrm{qC} 6, \mathrm{qC} 8, \log \mathrm{P}, \mathrm{qC} 8 \mathrm{a}, \mathrm{qC} 9$ & 0.99 & 0.97 & 0.94 & 0.10 & 11.04 \\
\hline 3 & $\mathrm{qO} 11, \mathrm{qC} 1, \mathrm{qC} 7, \mathrm{qC} 6, \mathrm{qC} 8, \mathrm{qC} 8 \mathrm{a}, \mathrm{qC} 9$ & 0.98 & 0.97 & 0.94 & 0.10 & 12.75 \\
\hline 4 & $\mathrm{qO} 11, \mathrm{qC} 1, \mathrm{qC} 7, \mathrm{qC} 6, \mathrm{qC} 8, \mathrm{qC} 8 \mathrm{a}$ & 0.98 & 0.96 & 0.94 & 0.10 & 14.54 \\
\hline 5 & $\mathrm{qO} 11, \mathrm{qC} 7, \mathrm{qC} 6, \mathrm{qC} 8, \mathrm{qC} 8 \mathrm{a}$ & 0.98 & 0.96 & 0.94 & 0.11 & 16.87 \\
\hline 6 & $\mathrm{qO} 11, \mathrm{qC} 7, \mathrm{qC} 8, \mathrm{qC} 8 \mathrm{a}$ & 0.97 & 0.95 & 0.93 & 0.11 & 17.61 \\
\hline
\end{tabular}

Abbreviations: $\quad$ SEE, standard error of the estimate; qO11, the atomic charge at Oxygen number 11; $\mathrm{qCn}$, the atomic charge at Carbon number n; LUMO, lowest unoccupied molecular orbital; MD, dipole moment. 
The selection of QSAR models refers to several statistical parameters such as $\mathrm{r}^{2}$, adjusted $\mathrm{R}, \mathrm{SEE}, \mathrm{F}_{\text {cal. }} / \mathrm{F}_{\text {tab. }}$ These parameters indicate the significance level of the model. Each of these parameters must meet criteria $\mathrm{r}^{2}>0.6$, SEE $<0.3$, and $\mathrm{F}_{\text {cal. }} / \mathrm{F}_{\mathrm{tab}} \geq 1 .{ }^{22,24}$ Table- 1 shows that all QSAR models have met the specified statistical parameters' criteria. Models 5 and 6 were chosen as the best model for the MCF-7 and HepG2 cancer cell lines, respectively. The selection of models 5 and 6 refers to the highest SEE and $\mathrm{F}_{\text {cal. }} / \mathrm{F}_{\text {tab. values }}$ than the other models. The higher value of each statistical parameter indicates the higher validity of the used model to predict anticancer activity. Equations-1 and 2 show the coefficient values of both models 5 and 6 , respectively.

$$
\begin{aligned}
\log \left(\mathrm{IC}_{50} \mathrm{MCF}-7\right)= & (7.85)+(100.54 \times \mathrm{LUMO})+(0.36 \times \mathrm{MD})-\left(3.02 \times \mathrm{qC}_{6}\right)-\left(1.71 \times \mathrm{qC}_{4}\right) \\
& -\left(7.98 \times \mathrm{qC}_{1}\right)
\end{aligned}
$$

Equation-1 showed that the anticancer activity of haloxanthones against the MCF-7 cancer cell line was determined by LUMO energy, dipole moment, the atomic charge on $\mathrm{C} 1, \mathrm{C} 4$, and $\mathrm{C} 6$. The high coefficient value of LUMO energy (100.54) indicates that even a slight change in this descriptor will significantly affect the anticancer activity against the MCF-7 cell line. Meanwhile, the negative atomic charge coefficients value indicates that the increasing descriptor amount will decrease the $\mathrm{IC}_{50}$ value (expected). Plot validation between the predictive and experimental $\mathrm{IC}_{50}$ values is shown in Fig.-2. It was found that the predictive $\mathrm{IC}_{50}$ value was not much different from the experimental $\mathrm{IC}_{50}$ value in both training and test data set as seen from the $\mathrm{R}^{2}$ values of 0.86 and 0.89 , respectively. The QSAR equation is valid when $\mathrm{R}^{2}>$ $0.5 .^{22}$ The high $\mathrm{R}^{2}$ value indicates that equation 1 could predict well the anticancer activity of Haloxanthone derivatives.

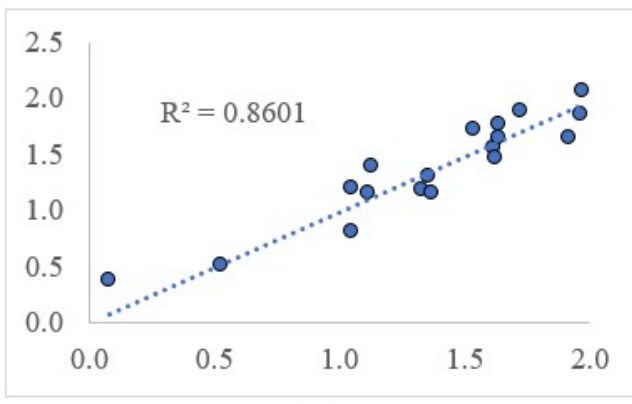

(a)

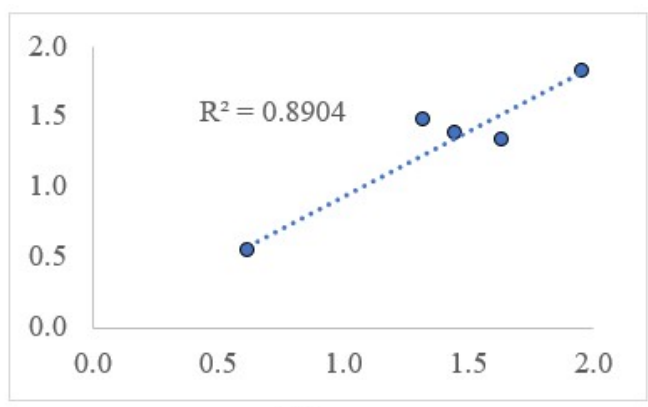

(b)

Fig.-2:The Plot of Predicted and Experimental IC 50 Values for MCF-7 Cell Line for (a) Training and (b) Test Set.

$\log \left(\mathrm{IC}_{50} \mathrm{HepG} 2\right)=-6.034-\left(1.198 \times \mathrm{qC}_{7}\right)+\left(9.274 \times \mathrm{qC}_{8 \mathrm{a}}\right)-\left(1.887 \times \mathrm{qC}_{8}\right)-\left(23.354 \times \mathrm{qO}_{11}\right)$

Equation-2 shows that the anticancer activity of haloxanthones against the HepG2 cell line is affected by the atomic charges on $\mathrm{C} 7, \mathrm{C} 8, \mathrm{C} 8 \mathrm{a}$, and $\mathrm{O} 11$. The negative value on the atomic charge coefficients of C7, $\mathrm{C} 8$, and $\mathrm{O} 11$ indicated that the anticancer activity gets higher when the charge of these atoms increased. The anticancer activity would be higher when the atomic charge on the C8a decreased. Equation 2 also showed that the anticancer activity of haloxanthones against HepG2 cell line is concentrating around the oxygen atom of the carbonyl group and the nearest carbon atom in ring A of the xanthone backbone. Meanwhile, descriptors that determine the anticancer activity against MCF-7 cell line spread in all aromatic rings $(\mathrm{A}, \mathrm{B}$, and $\mathrm{C})$ of the xanthone. , $^{3,427}$

Figure- 3 shows the validation plot between predictive and experimental $\mathrm{IC}_{50}$ values. The predictive $\mathrm{IC}_{50}$ value was not much different from the experimental $\mathrm{IC}_{50}$ value with $\mathrm{R}^{2}$ values of 0.94 (training set) and 0.93 (test set), respectively. Therefore, the prepared QSAR model is entirely valid and can be used to predict the anticancer activity of haloxanthones against the HepG2 cancer cells line. 
RASĀYAN J. Chem.

Vol. 14 | No. 3 |1927-1937| July - September | 2021

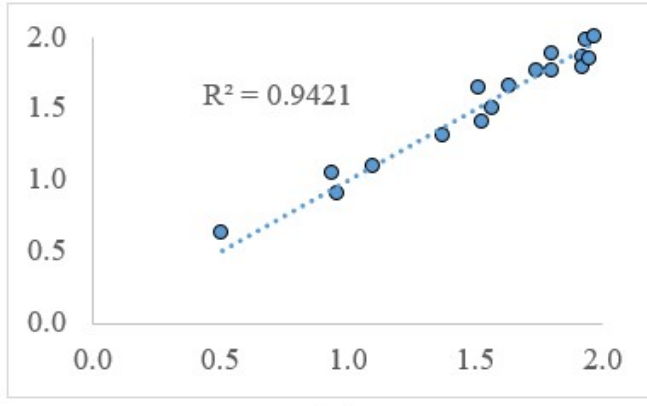

(a)

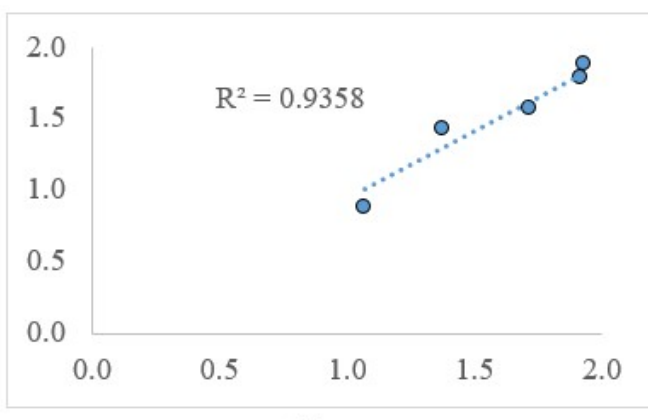

(b)

Fig.-3: The Plot of Predicted and Experimental IC $_{50}$ Values Against HepG2 Cell Line for (a) Training and (b) Test Set.

\section{Predictive $\mathrm{IC}_{50}$ Values of Haloxanthones against MCF-7 and HepG2 Cell Lines}

The predictive $\mathrm{IC}_{50}$ value of 87 haloxanthones derivatives ( 25 fluoroxanthone, 27 chloroxanthone, 18 bromoxanthone, and 17 iodoxanthone) was calculated using equations 1 and 2. Table-3 shows the five compounds with the lowest predictive $\mathrm{IC}_{50}$ values against the MCF-7 cancer cell line in each of the haloxanthone groups. Whereas Table-4 presents the lowest predictive $\mathrm{IC}_{50}$ value against the HepG2 cancer cell line.

Table-3: Potential Anticancer Agents in Each Haloxanthone Group Against MCF-7 Cancer Cell Line According to

\begin{tabular}{|c|c|c|c|c|c|c|c|c|c|}
\hline \multicolumn{10}{|c|}{ The Predicted $\mathrm{IC}_{50}$ Values } \\
\hline \multirow{2}{*}{\multicolumn{2}{|c|}{ Compounds }} & \multirow{2}{*}{$\begin{array}{l}\text { Molecular } \\
\text { Weight }\end{array}$} & \multirow[b]{2}{*}{ LUMO } & \multirow{2}{*}{$\begin{array}{l}\text { Dipole } \\
\text { Moment }\end{array}$} & \multicolumn{3}{|c|}{ Atomic Charge } & \multirow{2}{*}{$\begin{array}{l}\text { Log } \\
\mathrm{IC}_{50} \\
\text { pred. }\end{array}$} & \multirow{2}{*}{$\begin{array}{l}\mathrm{IC}_{50} \text { pred. } \\
(\mu \mathrm{g} / \mathrm{mL})\end{array}$} \\
\hline & & & & & qC6 & $\mathrm{qC} 4$ & $\mathrm{qC} 1$ & & \\
\hline \multicolumn{2}{|r|}{ Xanthone Structure } & 196.21 & -0.08 & 2.95 & -0.12 & -0.17 & -0.08 & 2.03 & 21.12 \\
\hline \multicolumn{10}{|c|}{ FLUORO-XANTHONE } \\
\hline $1 F X$ & $\begin{array}{l}\text { 2-hydroxyl-1,6- } \\
\text { difluoroxanthone }\end{array}$ & 248.19 & -0.09 & 5.39 & 0.34 & -0.15 & 0.31 & -2.72 & 0.0005 \\
\hline $2 \mathrm{FX}$ & $\begin{array}{l}\text { 2,6-dihydroxyl-4- } \\
\text { fluoroxanthone }\end{array}$ & 246.19 & -0.09 & 2.85 & 0.06 & 0.26 & 0.12 & -2.1 & 0.002 \\
\hline $3 \mathrm{FX}$ & $\begin{array}{l}\text { 2,8-dihydroxyl-1- } \\
\text { fluoroxanthone }\end{array}$ & 246.19 & -0.1 & 3.86 & -0.1 & -0.14 & 0.26 & -1.99 & 0.003 \\
\hline $4 \mathrm{FX}$ & $\begin{array}{l}\text { 2,6,8-trihydroxyl-4- } \\
\text { fluoroxanthone }\end{array}$ & 262.19 & -0.1 & 2.07 & 0.31 & 0.27 & -0.07 & -1.78 & 0.004 \\
\hline $5 \mathrm{FX}$ & $\begin{array}{l}\text { 2,6-dihydroxyl-1- } \\
\text { fluoroxanthone }\end{array}$ & 246.19 & -0.09 & 2.91 & -0.12 & -0.13 & 0.25 & -1.73 & 0.005 \\
\hline \multicolumn{10}{|c|}{ CHLORO-XANTHONE } \\
\hline $1 \mathrm{CX}$ & $\begin{array}{l}\text { 1-hydroxyl-2,8- } \\
\text { dichloroxanthone }\end{array}$ & 281.09 & -0.1 & 6.81 & -0.1 & -0.15 & 0.47 & -3.48 & 0.0001 \\
\hline $2 \mathrm{CX}$ & $\begin{array}{l}\text { 1-hydroxyl-2,7- } \\
\text { dichloroxanthone }\end{array}$ & 281.09 & -0.09 & 5.03 & -0.02 & -0.16 & 0.4 & -2.62 & 0.0007 \\
\hline $3 \mathrm{CX}$ & $\begin{array}{l}\text { 1-hydroxyl-5,7- } \\
\text { dichloroxanthone }\end{array}$ & 281.09 & -0.09 & 5.16 & 0.08 & -0.16 & 0.24 & -1.47 & 0.01 \\
\hline $4 \mathrm{CX}$ & $\begin{array}{l}\text { 1,6-dihydroxyl-4- } \\
\text { chloroxanthone }\end{array}$ & 262.65 & -0.08 & 2.83 & 0.28 & -0.43 & 0.24 & -1.14 & 0.02 \\
\hline $5 \mathrm{CX}$ & $\begin{array}{l}\text { 1-hydroxyl-4,7- } \\
\text { dichloroxanthone }\end{array}$ & 281.09 & -0.09 & 4.28 & -0.02 & -0.43 & 0.25 & -1.14 & 0.02 \\
\hline \multicolumn{10}{|c|}{ BROMO-XANTHONE } \\
\hline $1 \mathrm{BX}$ & $\begin{array}{l}\text { 1-hydroxyl-7- } \\
\text { bromoxanthone }\end{array}$ & 291.1 & -0.08 & 5.29 & -0.07 & -0.17 & 0.23 & 0.09 & 0.36 \\
\hline $2 \mathrm{BX}$ & $\begin{array}{l}6,8 \text {-dihydroxyl-4- } \\
\text { bromoxanthone }\end{array}$ & 307.1 & -0.09 & 3.86 & 0.31 & -0.49 & -0.06 & 0.34 & 0.67 \\
\hline $3 \mathrm{BX}$ & $\begin{array}{l}\text { 1-hydroxyl-8- } \\
\text { bromoxanthone }\end{array}$ & 291.1 & -0.08 & 4.62 & -0.1 & -0.16 & 0.23 & 0.41 & 0.75 \\
\hline
\end{tabular}


RASĀYAN J. Chem.

Vol. 14 | No. 3 |1927-1937| July - September | 2021

\begin{tabular}{c|l|r|r|r|r|r|r|r|r}
\hline 4BX & $\begin{array}{l}\text { 1,3-dihydroxyl-7- } \\
\text { bromoxanthone }\end{array}$ & 307.1 & -0.08 & 5.43 & -0.07 & -0.18 & 0.24 & 0.52 & 1.01 \\
\hline $5 \mathrm{BX}$ & $\begin{array}{l}\text { 1-hydroxyl-6- } \\
\text { bromoxanthone }\end{array}$ & 291.1 & -0.08 & 4.08 & -0.37 & -0.16 & 0.23 & 0.68 & 1.4 \\
\hline \multicolumn{7}{|c}{ IODO-XANTHONE } \\
\hline 1IX & $\begin{array}{l}\text { 1,8-dihydroxyl-2- } \\
\text { iodoxanthone }\end{array}$ & 354.1 & -0.09 & 4.52 & -0.1 & -0.16 & 0.24 & -0.73 & 0.07 \\
\hline $2 \mathrm{IX}$ & $\begin{array}{l}\text { 1-hydroxyl-6- } \\
\text { Iodoxanthone }\end{array}$ & 338.1 & -0.08 & 3.94 & -0.14 & -0.17 & 0.23 & -0.12 & 0.26 \\
\hline $3 \mathrm{IX}$ & $\begin{array}{l}\text { 1,8-dihydroxyl-7- } \\
\text { Iodoxanthone }\end{array}$ & 354.1 & -0.09 & 6.64 & -0.1 & -0.16 & 0.24 & -0.06 & 0.31 \\
\hline $4 \mathrm{IX}$ & $\begin{array}{l}\text { 1,3-dihydroxyl-5- } \\
\text { Iodoxanthone }\end{array}$ & 354.1 & -0.08 & 3.44 & -0.12 & -0.17 & 0.24 & 0.12 & 0.46 \\
\hline $5 \mathrm{IX}$ & $\begin{array}{l}\text { 1-hydroxyl-7- } \\
\text { Iodoxanthone }\end{array}$ & 338.1 & -0.08 & 5.06 & -0.11 & -0.17 & 0.23 & 0.18 & 0.51 \\
\hline
\end{tabular}

Abbreviations: LUMO, lowest unoccupied molecular orbital.

Table-3 shows that 20 haloxanthone compounds have strong anticancer activity against the MCF-7 cell line. Almost all of them had predictive $\mathrm{IC}_{50}$ value below $1 \mu \mathrm{g} / \mathrm{mL}$, except for compounds $\mathbf{4 B X}(1.01 \mu \mathrm{g} / \mathrm{mL})$ and 5BX $(1.40 \mu \mathrm{g} / \mathrm{mL})$. The Council of Scientific and Industrial Research (CSIR) classifies the cytotoxic activity of a compound into four categories based on the $\mathrm{IC}_{50}$ value, including inactive $\left(\mathrm{IC}_{50}>50 \mu \mathrm{g} / \mathrm{mL}\right)$, weak $(15-50 \mu \mathrm{g} / \mathrm{mL})$, moderate $(6.25-15 \mu \mathrm{g} / \mathrm{mL})$, and strong/potent $(<6.25 \mu \mathrm{g} / \mathrm{mL})$. Overall, fluoroxanthone compounds have better anticancer activity than other haloxathone derivatives. However, the lowest predictive $\mathrm{IC}_{50}$ value was obtained for 1-hydroxy-2,8-dichloroxanthone (1CX), which was 0.0001 $\mu \mathrm{g} / \mathrm{mL}$. This value is much lower when compared to the experimental $\mathrm{IC}_{50}$ value of several standard drug compounds, such as doxorubicin, rifampin, and 5-fluorouracil. ${ }^{25}$

A low predictive $\mathrm{IC}_{50}$ value for compounds $\mathbf{1 C X}$ is due to the significant change in LUMO energy and the atomic charge on the $\mathrm{C} 1$ atom. LUMO energy and atomic charge on $\mathrm{C} 1$ are two factors that influence anticancer activity based on the QSAR model. The addition of two $\mathrm{Cl}$ atoms at positions $\mathrm{C} 2$ and $\mathrm{C} 8$ can reduce the LUMO energy by -0.02 (compared to the xanthone structure). Also, the presence of hydroxyl group at the $\mathrm{C} 1$ atom can increase the atomic charge at that position by 0.55 .

The presence of hydroxyl and halogen groups at $\mathrm{C} 1$ and $\mathrm{C} 2$ would significantly increase the atomic charge on $\mathrm{C} 1$. This can be seen in the 1FX, 3FX, 5FX, 9FX, 13FX, 1CX, and $2 \mathrm{CX}$ compounds. The addition of fluoro group at $\mathrm{C} 4$ and $\mathrm{C} 6$ positions can also increase the atomic charge on each position (see compounds 1FX, 2FX, and 4FX). However, the addition of other halogen atoms $(\mathrm{Cl}, \mathrm{Br}$, and $\mathrm{I})$ in this position decreases the value of the atomic charge as shown in compounds $4 \mathbf{C X}, \mathbf{2 B X}$, and 1IX compounds. The atomic charge at $\mathrm{C} 4$ and $\mathrm{C} 6$ can be leveled by adding $\mathrm{Cl}, \mathrm{Br}$, or I groups in the ortho position to $\mathrm{C} 4$ and $\mathrm{C} 6$.

Table-4: Potential anticancer agents in each haloxanthone group against HepG2 cancer cell line according to the predicted $\mathrm{IC}_{50}$ values

\begin{tabular}{|c|c|c|c|c|c|c|c|c|}
\hline \multirow{2}{*}{\multicolumn{2}{|c|}{ Compounds }} & \multirow{2}{*}{$\begin{array}{l}\text { Molecular } \\
\text { Weight }\end{array}$} & \multicolumn{4}{|c|}{ Atomic Charge } & \multirow{2}{*}{$\begin{array}{l}\text { Log } \\
\text { IC }_{50} \\
\text { pred. }\end{array}$} & \multirow{2}{*}{$\begin{array}{l}\mathrm{IC}_{50} \text { pred. } \\
(\mu \mathrm{g} / \mathrm{mL})\end{array}$} \\
\hline & & & $\mathrm{qC} 7$ & qC8a & $\mathrm{qC} 8$ & qO11 & & \\
\hline & Xanthone Structure & 196.21 & -0.15 & -0.12 & -0.08 & -0.37 & 1.76 & 11.35 \\
\hline \multicolumn{9}{|c|}{ FLUORO-XANTHONE } \\
\hline $6 \mathrm{FX}$ & 1-hydroxyl-8-fluoroxanthone & 230.20 & -0.19 & -0.16 & 0.31 & -0.30 & -0.90 & 0.03 \\
\hline $7 \mathrm{FX}$ & 1,3-dihydroxyl-8-fluoroxanthone & 246.19 & -0.19 & -0.16 & 0.31 & -0.30 & -0.75 & 0.04 \\
\hline $8 \mathrm{FX}$ & 2-hydroxyl-1,8-difluoroxanthone & 248.19 & -0.19 & -0.15 & 0.32 & -0.30 & -0.70 & 0.05 \\
\hline 9FX & 1-hydroxyl-7-fluoroxanthone & 230.20 & 0.32 & -0.14 & -0.14 & -0.33 & 0.22 & 0.38 \\
\hline 10FX & 3-hydroxyl-8-fluoroxanthone & 230.20 & -0.19 & -0.14 & 0.32 & -0.34 & 0.22 & 0.38 \\
\hline \multicolumn{9}{|c|}{ CHLORO-XANTHONE } \\
\hline $2 \mathrm{CX}$ & 1-hydroxyl-2,7-dichloroxanthone & 281.09 & -0.32 & -0.16 & 0.03 & -0.32 & 0.34 & 0.62 \\
\hline $6 \mathrm{CX}$ & 1-hydroxyl-7-chloroxanthone & 246.65 & -0.32 & -0.16 & 0.03 & -0.33 & 0.49 & 0.76 \\
\hline $3 \mathrm{CX}$ & 1-hydroxyl-5,7-dichloroxanthone & 281.09 & -0.32 & -0.15 & 0.04 & -0.32 & 0.44 & 0.77 \\
\hline
\end{tabular}


RASĀYAN J. Chem.

Vol. 14 | No. 3 |1927-1937| July - September | 2021

\begin{tabular}{l|l|r|r|r|r|r|r|r}
\hline 7CX & 1-hydroxyl-6-chloroxanthone & 246.65 & -0.05 & -0.14 & -0.09 & -0.33 & 0.62 & 1.02 \\
\hline 8CX & 1,3-dihydroxyl-7-chloroxanthone & 262.65 & -0.32 & -0.16 & 0.02 & -0.33 & 0.62 & 1.11 \\
\hline \multicolumn{10}{c}{ BROMO-XANTHONE } \\
\hline 5BX & 1-hydroxyl-6-bromoxanthone & 291.10 & -0.09 & -0.14 & -0.08 & -0.33 & 0.64 & 1.27 \\
\hline 1BX & 1-hydroxyl-7-bromoxanthone & 291.10 & -0.40 & -0.15 & -0.03 & -0.33 & 0.77 & 1.72 \\
\hline 6BX & 1,3-dihydroxyl-6-bromoxanthone & 307.10 & -0.09 & -0.14 & -0.08 & -0.34 & 0.77 & 1.82 \\
\hline 7BX & 6,8-dihydroxyl-1-bromoxanthone & 307.10 & 0.26 & -0.11 & -0.10 & -0.35 & 0.87 & 2.27 \\
\hline 4BX & 1,3-dihydroxyl-7-bromoxanthone & \multicolumn{10}{|c|}{307.10} & -0.39 & -0.15 & -0.03 & -0.33 & 0.90 & 2.44 \\
\hline \multicolumn{10}{|c|}{ IODO-XANTHONE } \\
\hline 2IX & 1-hydroxyl-7-Iodoxanthone & 338.10 & -0.16 & -0.14 & -0.08 & -0.33 & 0.64 & 1.47 \\
\hline 1IX & 1-hydroxyl-6-Iodoxanthone & 338.10 & -0.13 & -0.14 & -0.08 & -0.33 & 0.71 & 1.74 \\
\hline 3IX & 8-hydroxyl-2-Iodoxanthone & 338.10 & -0.15 & -0.07 & 0.23 & -0.33 & 0.77 & 2.00 \\
\hline 6IX & 1,3-dihydroxyl-7-Iodoxanthone & 354.10 & -0.15 & -0.14 & -0.08 & -0.33 & 0.77 & 2.08 \\
\hline 7IX & 8-hydroxyl-3-Iodoxanthone & 338.10 & -0.15 & -0.06 & 0.23 & -0.33 & 0.84 & 2.32 \\
\hline
\end{tabular}

Table-4 shows that 20 haloxanthone compounds have strong anticancer activity against HepG2 cells line with predictive $\mathrm{IC}_{50}$ value of $0.03-2.44 \mu \mathrm{g} / \mathrm{mL}$. Overall, the predictive $\mathrm{IC}_{50}$ value of haloxanthones against the HepG2 cell line was still higher than the predictive $\mathrm{IC}_{50}$ value against the MCF-7 cell line. This indicates that the anticancer activity of haloxanthones tends to be higher against MCF-7 than the HepG2 cell lines.

The fluoro-xanthone group has better anticancer activity than the other haloxanthone groups (Chloro-, Bromo- and Iodo-xanthone). The addition of both fluoro and hydroxyl groups at positions $\mathrm{C} 1$ and $\mathrm{C} 8$ caused an increment in the atomic charge of $\mathrm{O} 11$ and $\mathrm{C} 8$, and a decrement in the atomic charge of C8a. That has an impact on decreasing the predictive $\mathrm{IC}_{50}$ values for $6 \mathbf{F X}, 7 \mathbf{F X}$, and $8 \mathrm{FX}$ compounds. The addition of chloro-/bromo- group at $\mathrm{C} 1$ or $\mathrm{C} 8$ atoms affected the charge decrement on the $\mathrm{C} 8$ and $\mathrm{O} 11$ atoms, which causes an increase in the predictive $\mathrm{IC}_{50}$ values. The increment of the $\mathrm{C} 8$ and $\mathrm{O} 11$ atomic charges occurs when the chloro- or bromo- groups are located at the $\mathrm{C} 7$ position. However, the addition can also cause an unexpected decrement in the atomic charge of the $\mathrm{C} 7$ atom as shown in $\mathbf{2 C X}, \mathbf{6 C X}, \mathbf{8 C X}, \mathbf{1 B X}$, and $\mathbf{4 B X}$ compounds. This factor then causes the predictive $\mathrm{IC}_{50}$ value of chloro- and bromo-xanthone to be higher (lower activity) than fluoro-xanthone.

Based on QSAR studies, 26 haloxanthone compounds have potential anticancer activities against MCF-7 and HepG2 cell lines. These compounds have a predictive $\mathrm{IC}_{50}$ value of less than $6.25 \mu \mathrm{g} / \mathrm{mL}$ based on calculations using the obtained QSAR model (equations 1 and 2). The prediction of the $\mathrm{IC}_{50}$ value of the 26 haloxanthon derivatives is shown in Table-5. Molecular docking studies were carried out on five haloxanthone derivatives to assess their interactions with the targeted protein.

Table-5: Predictive $\mathrm{IC}_{50}$ value of 26 haloxanthone derivatives against MCF-7 and HepG2 cancer cells line

\begin{tabular}{c|l|r|r}
\hline \multicolumn{2}{c}{ Compounds } & \multicolumn{2}{c}{ IC50 Predictive $(\mu \mathrm{g} / \mathrm{mL})$} \\
\cline { 3 - 4 } \multicolumn{2}{c|}{} & \multicolumn{1}{c}{ MCF-7 } & \multicolumn{1}{c}{ HepG2 } \\
\hline 8FX & 2-hydroxyl-1,8-difluoroxanthone & 0.025 & 0.05 \\
\hline 11FX & 2-hydroxyl-1,7-difluoroxanthone & 0.04 & 0.44 \\
\hline 2CX & 1-hydroxyl-2,7-dichloroxanthone & 0.0007 & 0.62 \\
\hline $12 \mathrm{FX}$ & 1-hydroxyl-5,7-dichloroxanthone & 0.01 & 0.77 \\
\hline $6 \mathrm{CX}$ & 1-hydroxyl-6-fluoroxanthone & 0.014 & 1.01 \\
\hline $1 \mathrm{FX}$ & 2-hydroxyl-7-chloroxanthone & 0.21 & 0.76 \\
\hline $9 \mathrm{CX}$ & 1-hydroxyl-5-chloroxanthone & 0.0005 & 1.16 \\
\hline $9 \mathrm{FX}$ & 1-hydroxyl-7-fluoroxanthone & 0.02 & 1.14 \\
\hline $13 \mathrm{FX}$ & 2-hydroxyl-1-fluoroxanthone & 0.57 & 0.38 \\
\hline $6 \mathrm{FX}$ & 1-hydroxyl-8-fluoroxanthone & 0.08 & 1.36 \\
\hline $10 \mathrm{CX}$ & 1,3-dihydroxyl-5-chloroxanthone & 1.15 & 0.03 \\
\hline $11 \mathrm{CX}$ & 1-hydroxyl-6-chloroxanthone & 0.13 & 1.65 \\
\hline $12 \mathrm{CX}$ & 1,3-dihydroxyl-7-chloroxanthone & 0.64 & 1.02 \\
\hline $1 \mathrm{IX}$ & 1-hydroxyl-6-Iodoxanthone & 0.63 & 1.11 \\
\hline $2 \mathrm{IX}$ & 1-hydroxyl-7-Iodoxanthone & 0.26 & 1.74 \\
\hline
\end{tabular}


RASĀYAN J. Chem.

Vol. 14 | No. 3 |1927-1937| July - September | 2021

\begin{tabular}{c|l|r|r}
\hline 1BX & 1-hydroxyl-7-bromoxanthone & 0.36 & 1.72 \\
\hline 7FX & 1,3-dihydroxyl-8-fluoroxanthone & 1.91 & 0.04 \\
\hline 14FX & 1,3-dihydroxyl-7-fluoroxanthone & 1.59 & 0.56 \\
\hline 5BX & 1-hydroxyl-6-bromoxanthone & 1.40 & 1.27 \\
\hline 4BX & 1,3-dihydroxyl-7-bromoxanthone & 1.01 & 2.44 \\
\hline 5IX & 1,3-dihydroxyl-6-Iodoxanthone & 0.99 & 2.51 \\
\hline 6IX & 1,3-dihydroxyl-7-Iodoxanthone & 1.43 & 2.08 \\
\hline 13CX & 1,3-dihydroxyl-6-chloroxanthone & 3.11 & 1.48 \\
\hline 15FX & 4-hydroxyl-3-fluoroxanthone & 1.13 & 5.92 \\
\hline 6BX & 1,3-dihydroxyl-6-bromoxanthone & 5.94 & 1.82 \\
\hline
\end{tabular}

\section{Molecular Docking Studies of Haloxanthones against c-JNK Protein}

The molecular docking study aims to determine the interactions between ligands and amino acid residues on c-JNK proteins that play a role in inhibiting cancer cell growth ${ }^{26}$. Molecular docking studies were performed using the three-dimensional structure of the c-JNK protein from the www.worldwide protein databank with code $4 \mathrm{e} 73$. Table- 6 shows the value of RMSD, free binding energy, and the interaction between ligands and amino acid residues due to molecular docking studies.

Table-6: The RMSD and free binding energy values, and interactions between ligands and amino acid residues on the c-JNK protein

\begin{tabular}{|c|c|c|c|}
\hline Compound & $\begin{array}{l}\mathrm{RMSD} \\
(\AA)\end{array}$ & $\begin{array}{l}\text { Free binding energy } \\
(\mathrm{kcal} / \mathrm{mol})\end{array}$ & Binding interaction \\
\hline 0NR & 0.81 & -8.54 & A.t. \\
\hline $2 \mathrm{CX}$ & 1.41 & -6.73 & 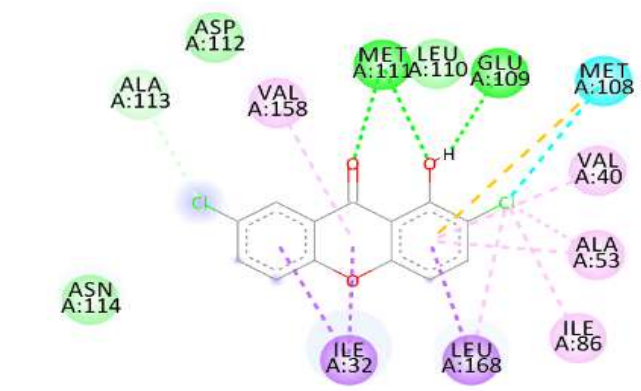 \\
\hline $3 \mathrm{CX}$ & 1.06 & -6.51 & 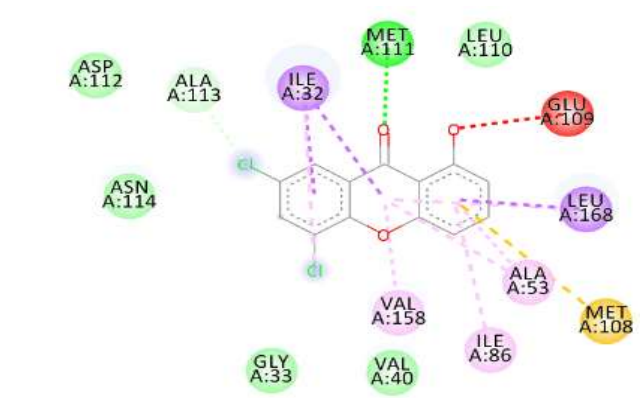 \\
\hline
\end{tabular}


RASĀYAN J. Chem.

Vol. 14 | No. 3 |1927-1937| July - September | 2021

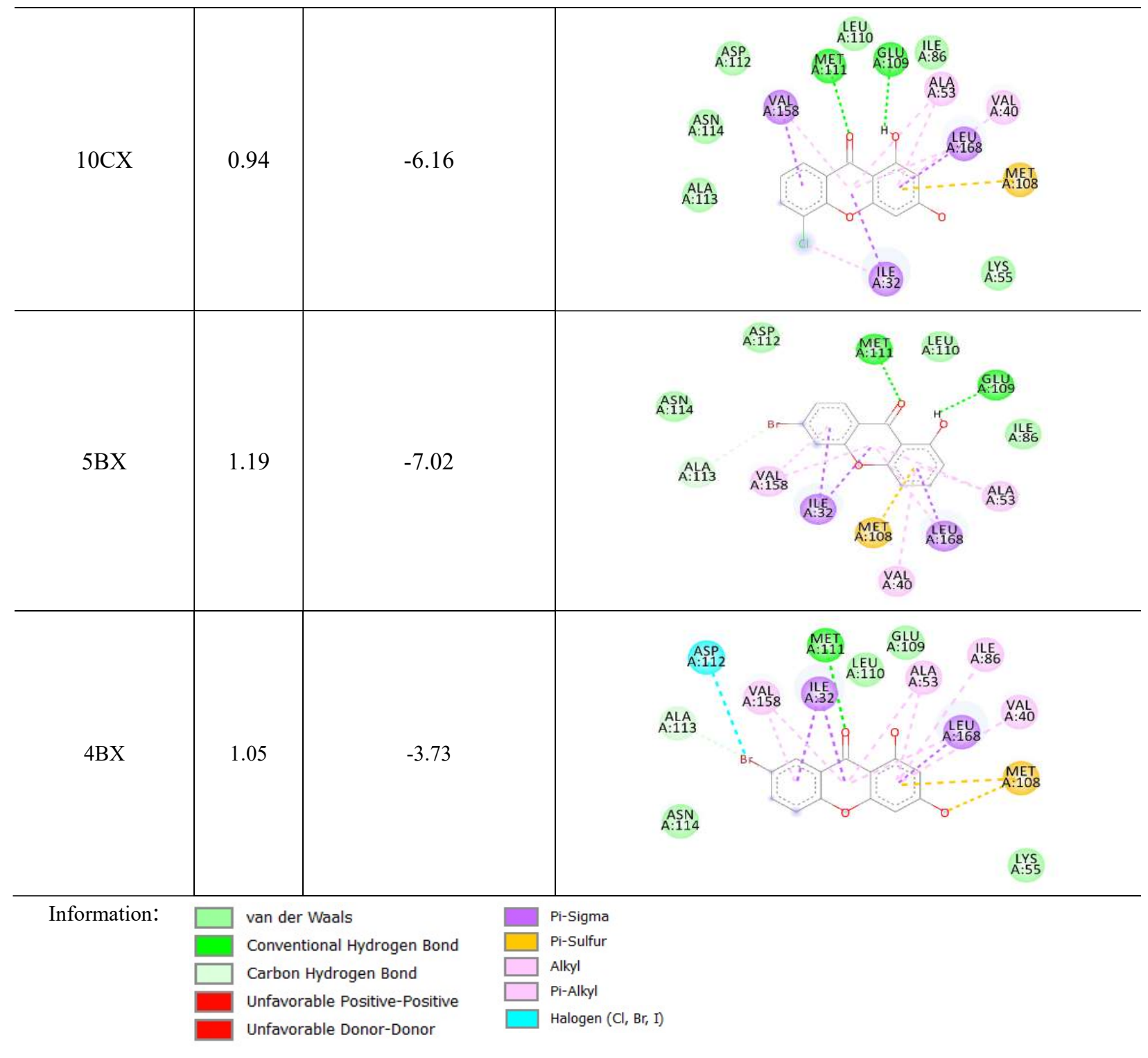

Table- 6 shows that free binding energy between the native ligands 0NR and c-JNK protein was 8.54 $\mathrm{kcal} / \mathrm{mol}$ with several types of interactions formed (bonding and non-bonding). Types of interactions include van der walls interactions (GLU109, LEU110, GLY33, SER34, ASN114, ALA113, and ASP112), hydrogen bonds (MET111), hydrogen-carbon bonds (SER115), pi-sigma (ILE32, LEU168, VAL40), alkyl and pi-alkyl (ALA53, Ile86, VAL158, and ALA42), as well as unfavorable positive-positive and donors (LYS30). Several types of interactions are very influential on the c-JNK protein activity. ${ }^{26}$

Table-5 also shows that the docking of five chloro- and bromo-xanthone derivatives to the c-JNK protein produces an RMSD value of less than $2 \AA$. It is indicated that all compounds' conformation is not much different from the native ligand (0NR). ${ }^{23}$ The free binding energy produced by the $\mathbf{2 C X}, \mathbf{3 C X}, \mathbf{1 0 C X}, \mathbf{5 B X}$, and $4 \mathrm{BX}$ compounds against the c-JNK protein was $-6.73,-6.51,-6.16,-7.02$, and $-3.73 \mathrm{kcal} / \mathrm{mol}$, respectively. Overall, the resulting free binding energy value was lower than that of the native 0NR ligand, which is remarkable. However, the number of hydrogen bonds produced by $\mathbf{2 C X}$ and $10 \mathrm{CX}$ compounds is higher than 0 NR ligands. The $\mathbf{2 C X}$ compound produces three hydrogen bonds to the amino acid residues MET111, LEU110, and GLU109. Meanwhile, the 10CX compound produces two hydrogen bonds to the amino acid residues of MET111 and GLU109. 
RASĀYAN J. Chem.

Vol. 14 | No. 3 |1927-1937| July - September | 2021

\section{CONCLUSION}

Twenty-six haloxanthone derivatives were found to give potential anticancer activity against MCF-7 and HepG2 cell lines with predictive $\mathrm{IC}_{50}$ values less than $6.25 \mu \mathrm{g} / \mathrm{mL}$. The LUMO energy, dipole moment, and atomic charge at $\mathrm{C} 1, \mathrm{C} 4$, and $\mathrm{C} 6$ determine the anticancer activity of the haloxanthones against the MCF-7 cancer cell line. Meanwhile, the anticancer activity of haloxanthones against the HepG2 cell line depends on the atomic charge at $\mathrm{C} 7, \mathrm{C} 8, \mathrm{C} 8 \mathrm{a}$, and $\mathrm{O} 11$. Haloxanthones affected the activity of the c-JNK protein through the formation of hydrogen bonding interactions with MET111 and GLU109, alkyl/pi-alkyl with VAL40, and halogen interactions with MET108 and ASP112.

\section{ACKNOWLEDGEMENT}

The authors thank the Department of Chemistry, Universitas Gadjah Mada for granting permission to use the facility to implement this research. The Gaussian 09 licenses were provided by Austrian-Indonesian Centre (AIC) for the computational program is gratefully acknowledged. Financial support from the Ministry of Research and Technology, the Republic of Indonesia through Penelitian Disertasi Doktor $(P D D)$ Scheme is also greatly appreciated.

\section{REFERENCES}

1. C.P. Wild, E. Weiderpass, B.W. Stewart, World Cancer Report, Cancer Research for cancer prevention, International Agency for Research on Cancer, Lyon, 9(2020), http://publications.iarc.fr/586

2. J. Kryczka, J. Boncela, Molecules, 23(2), 331(2018), https://doi.org/10.3390/molecules23020331

3. E. Yuanita, H.D. Pranowo, M. Mustofa, R.T. Swasono, J. Syahri, J. Jumina, Chemistry Journal of Moldova. 14(1), 68(2019), http://dx.doi.org/10.19261/cjm.2018.520

4. I. Miladiyah, J. Jumina, S. M. Haryana, M. Mustofa, Drug Design, Development and Therapy, 12(3), 149(2018), https://doi.org/10.2147/DDDT.S149973

5. J. Liu, J. Zhang, H. Wang, Z. Liu, C. Zhang, Z. Jiang, H. Chen, European Journal of Medicinal Chemistry, 133, 50(2017), https://doi.org/10.1016/j.ejmech.2017.03.068

6. E. Yuanita, H.D. Pranowo, D. Siswanta, R.T. Swasono, M. Mustofa, A.K. Zulkarnain, J. Syahri, J. Jumina, Chemistry and Chemical Technology, 12(3), 290(2018), https://doi.org/10.23939/chcht $\underline{12.03 .290}$

7. V. Kuete, L.P. Sandjo, J.L.N. Ouete, H. Fouotsa, B. Wiench, T. Efferth, Phytomedicine, 21(3), 315(2014), https://doi.org/10.1016/j.phymed.2013.08.018

8. P. Li, W. Tian, X. Ma, Molecular Cancer, 13, 138(2014), https://doi.org/10.1186/1476-4598-13-138

9. T. Shan, X. Cui, W. Li, W. Lin, H. Lu, Y. Li, X. Chen, T. Wu, Acta Pharmacologica Sinica, 35, 1065(2014), https://doi.org/10.1038/aps.2014.43

10. Y.S. Won, J.H. Lee, S.J. Kwon, J.Y. Kim, K.H. Park, M.K. Lee, K.I. Seo, Food and Chemical Toxicology, 66, 158(2014), https://doi.org/10.1016/i.fct.2014.01.040

11. S. Kritsanawong, S. Innajak, M. Imoto, R. Watanapokasin, International Journal Oncology, 48, 2155(2016), https://doi.org/10.3892/ijo.2016.3399

12. H.H. Kwak, I.R. Kim, H.J. Kim, B.S. Park, S.B. Yu, Evidence-Based Complementary Alternative Medicine, 12, 1(2016), https://doi.org/10.1155/2016/5352412

13. H.N. Lee, H.Y. Jang, H.J. Kim, S.A. Shin, G.S. Choo, Y.S. Park, S.K. Kim, J.Y. Jung, International Journal of Molecular Medicine, 37, 939(2016), https://doi.org/10.3892/ijmm.2016.2517

14. M. Muchtaridi, S. Megantara, D. Dermawan, M. Yusuf, Rasayan Journal of Chemistry, 12(4), 1927(2019), http://dx.doi.org/10.31788/RJC.2019.1245391

15. J.J. Wang, B.J.S. Sanderson, W. Zhang, Food and Chemical Toxicology, 49, 2385(2011), https://doi.org/10.1016/j.fct.2011.06.051

16. T. Onodera, Y. Takenaka, S. Kozaki, T. Tanahashi, Y. Mizushima, International Journal of Oncology, 48, 1145(2016), https://doi.org/10.3892/ijo.2016.3321

17. X. Yang, S. Wang, Y. Ouyang, Y. Tu, A. Liu, Y. Tian, M. He, R. Pi, Neuroscience Letter, 626, 6(2016), https://doi.org/10.1016/j.neulet.2016.05.012

18. H. Kikuchi, T. Ohtsuki, T. Koyano, T. Kowithayakorn, T. Sakai, M. Ishibashi, Journal of Natural Products, 73(3), 452(2010), https://doi.org/10.1021/np900404e 
RASĀYAN J. Chem.

Vol. 14 | No. 3 |1927-1937| July - September | 2021

19. S. Mohan, S.I. Abdelwahab, B. Kamalidehghan, S. Syam, K.S. May, N.S.M. Harmal, N. Shafifiyaz, A.H.A. Hadi, N.M. Hashim, M. Rahmani, M.M.E. Taha, S.C. Cheah, A. Zajmi, Phytomedicine, 19(11), 1007(2012), https://doi.org/10.1016/j.phymed.2012.05.012

20. J. Tangpong, S. Miriyala, T. Noel, C. Sinthupibulyakit, P. Jungsuwadee, D.K. St. Clair, Neuroscience, 175, 292(2011), https://doi.org/10.1016/j.neuroscience.2010.11.007

21. Z.M. Yang, J. Huang, J.K. Qin, Z.K. Dai, W.L. Lan, G.F. Su, H. Tan, F. Yang, European Journal of Medicinal Chemistry, 85, 487(2014), https://doi.org/10.1016/j.ejmech.2014.07.076

22. N. Frimayanti, M.L. Yam, H.B. Lee, R. Othman, S.M. Zain, N.M. Rahman, International Journal of Molecular Sciences, 12(12), 8626(2011), https://doi.org/10.3390/ijms12128626

23. L.G. Ferreira, R.N. dos Santos, G. Oliva, A.D. Andricopulo, Molecules, 20(7), 13384(2015), https://doi.org/10.3390/molecules200713384

24. T. Puzyn, J. Leszczyniski, M.T.D. Cronin, Recent Advances in QSAR Studies: Methods and Application, New York, 261(2010), https://doi.org/10.1007/978-1-4020-9783-6_9

25. S. Alam, F. Khan, Drug Design Development and Therapy, 8, 183(2014), https://doi.org/10.2147/DDDT.S51577

26. C. Davies, C. Tournier, Biochemical Society Transaction, 40(1), 85(2012), https://doi.org/10.1042/BST20110641

27. B. Vemu, M.C. Nauman, J.P. Veenstra, J.J. Johnson, International Journal of Nutrition, 42(2), 38(2019), https://doi.org/10.3390/nu13030773

[RJC-6214/2020] 